\title{
Effect of and Salinity Atthe Urban area and its Identification by using Remote Sensing \& GIS Technique. A Case Study of Haryana, India
}

\author{
Neeraj Kumar*, SK Kamra, Satyendra Kumar, Bhaskar Narjary, Vivekanand and Ramesh Abhishek \\ Department of Irrigation \& Drainage Engineering, Central Soil Salinity Research Institute, India
}

Submission: December 22, 2017; Published: March 19, 2018

*Corresponding author: Neeraj Kumar, Department of Irrigation \& Drainage Engineering, Central Soil Salinity Research Institute, India, Email: neerajwre@gmail.com

\section{Introduction}

The declination of the water table is one of the major problems of the world. It has been observed in most of developing countries that the annual water table is declining due to excess use in agriculture and climate change [1], but in few part of the world, the problem of rising in water table depth has been encountered in past few decades. Rising water table in an arid region is the cause of salinity. A lot of research has been done in past few decades to estimate the losses due to salinity. Most of them are on agriculture crop yield [2]. Salinity causes dampness in the wall and it is also responsible for corrosion in steel specimens. The present studies have been conducted in one of the major states of India where the worst effect of salinity has been encountered in buildings. The salt accumulation on the wall up to $1 \mathrm{~m}$ above from the surface can be easily found in almost every house in two districts Rohtak and Jhajjar of Haryana. These studies also emphasize to develop a new methodology for salinity monitoring over a large urban and agricultural area by using various salinity and building Index $[3,4]$.

\section{Materials and Methods}

\section{Steps involved in methodology}

Water table depth analysis: In this study the observation well data pre-monsoon and post-monsoon of the year 2013 and 2015 data of Central Ground Water board published on 2013 and 2015 has been taken and it has been analyzed by using interpolation tool in GIS domain and raster map has been made.

Soil and water sample analysis: Water quality data published by Central Ground Water board or year 2013 and 2015 has been having been taken and the data of EC, PH, RSC, and SAR has been mapped over entire study area and raster map has been made [5].
Built-up area extraction by using NDBI: Normalized Difference Building Index has been used to identify the residential building in the study area.

Overlay Technique: These data sets have been exported overlay tool in GIS domain and raster map has been made.

Verification of Output Data: The output data obtained after analysis by overlay tool has been verified by using various salinity index [6] (Figure 1).

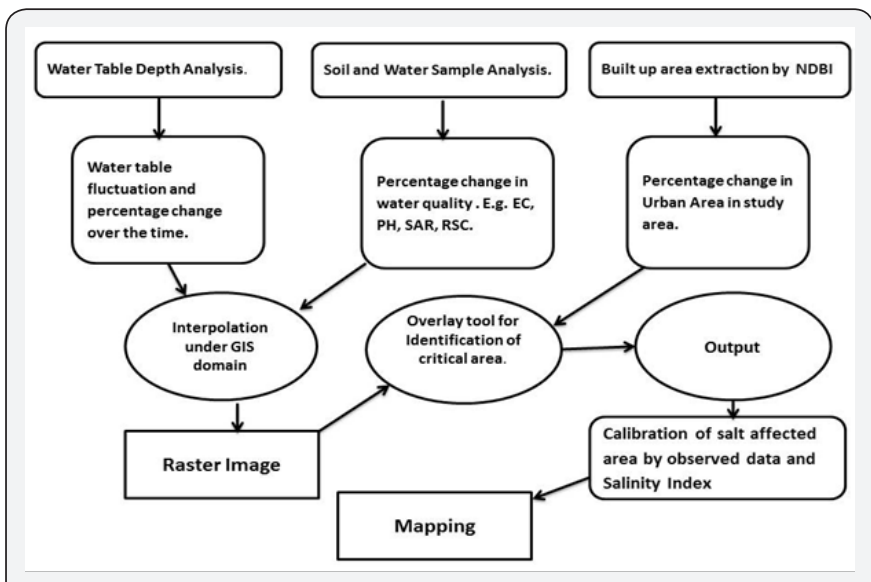

Figure 1: The flow chart of the methodology.

Results and Conclusion

a. The present study has been done to identify the new saline and alkali area of Haryana state of India, Including its effect on urban and agriculture area. The result obtained by this study shows that out of 19 districts of only 5 districts of Haryana was affected in the year 2013 but in the year 2015, the saline and alkaline affected district tolls to 8. Rohtak and Jhajjar are worst affected (Figure 2). 


\section{Civil Engineering Research Journal}

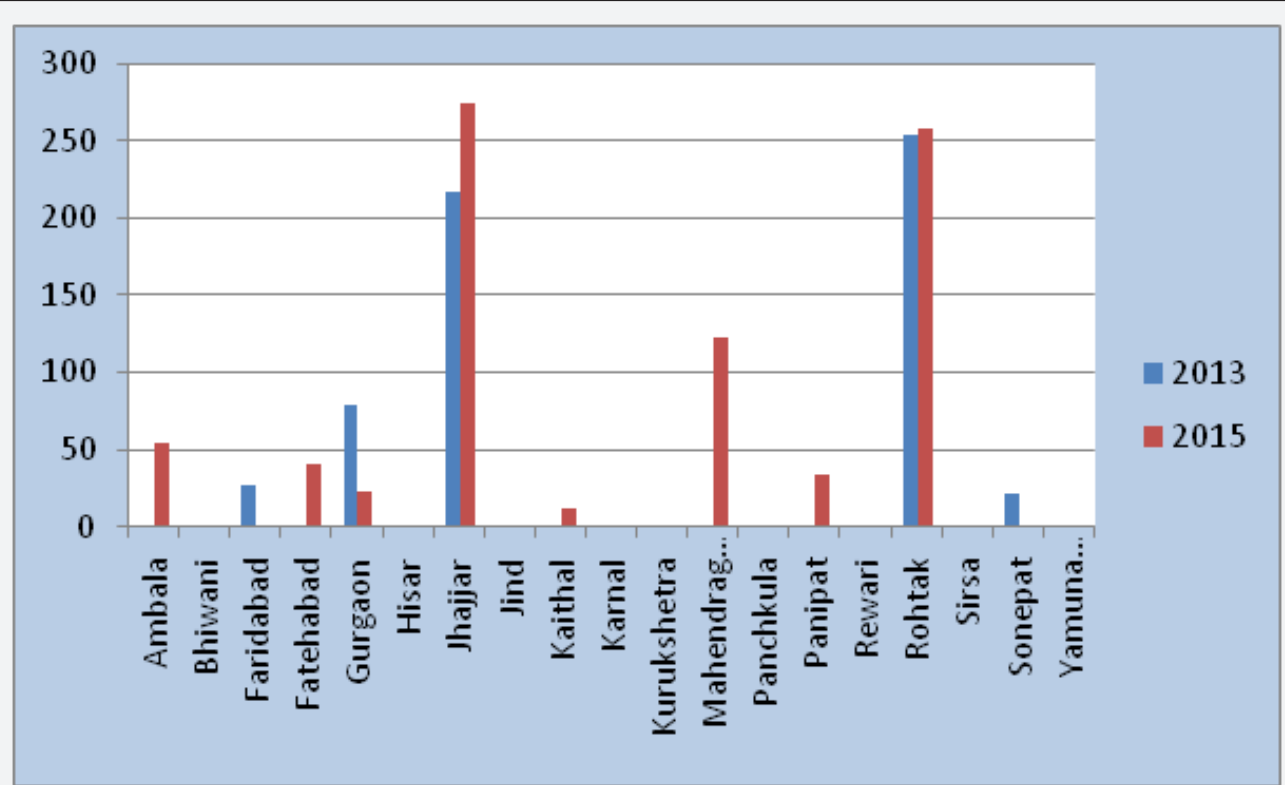

Figure 2: District wise salt affected area in Sq. Km. of Haryana, India.

b. Remote sensing and GIS tool can be used to identify the salt-affected land and also the estimation of sodium hazard at urban area (Figure 3). c. Remote Sensing indexes are very useful to detect salt affected area.

d. This technique can be used in almost all over the globe.

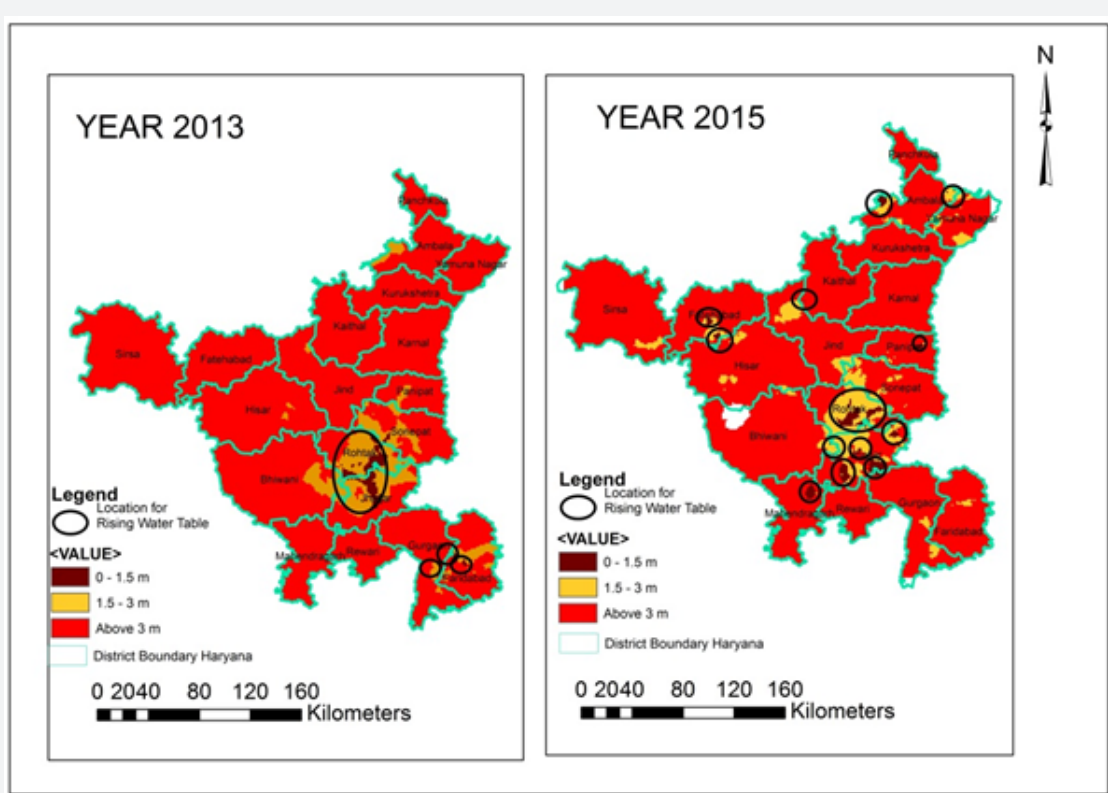

Figure 3: District wise salt affected area and location of Haryana, India.

\section{References}

1. Ashutosh M (2017) Changing Temperature and Rainfall Patterns of Uttarakhand. Int J Environ Sci Nat Res 7(4): 555716.

2. Wenbo Li, Qing Li (2017) Effect of Environmental Salt Stress on Plants and the Molecular Mechanism of Salt Stress Tolerance. Int J Environ Sci Nat Res 7(3): 555714.

3. Zha Y, Gao J, Ni S (2013) Use of normalized difference built-up index in automatically mapping urban areas from TM imagery. International Journal of Remote Sensing 24(3): 583-594.
4. Xu H (2007) Extraction of urban built-up land features from Landsat imagery using a the maticoriented index combination technique. Photogrammetric Engineering \& Remote Sensing 73(12): 1381-1391.

5. Anand AV (2013) Central Ground Water Board Ministry of Water Resources, Government of India. Ground Water Brochure Nellore District, Andhra Pradesh, India.

6. Azabdaftari A, Sunar F (2016) Soil Salinity Mapping Using Multi temporal Landsat Data. ISPRS-International Archives of the Photogrammetry, Remote Sensing and Spatial Information Sciences. 


\section{Your next submission with Juniper Publishers will reach you the below assets}

- Quality Editorial service

- Swift Peer Review

- Reprints availability

- E-prints Service

- Manuscript Podcast for convenient understanding

- Global attainment for your research

- Manuscript accessibility in different formats ( Pdf, E-pub, Full Text, Audio)

- Unceasing customer service

Track the below URL for one-step submission https://juniperpublishers.com/online-submission.php 